\title{
Pengaruh Aktivitas Masyarakat di pinggir Sungai (Rumah Terapung) terhadap Pencemaran Lingkungan Sungai Kahayan Kota Palangka Raya Kalimantan Tengah
}

\author{
Novrianti \\ Program Studi Teknik Lingkungan Universitas Muhammadiyah Palangkaraya \\ email: vnovrianti@yahoo.co.id
}

\begin{abstract}
ABSTRAK. Sungai Kahayan merupakan salah satu sungai yang terdapat di Kalimantan Tengah. Peranannya dalam kehidupan masyarakat sangat banyak, seperti sebagai jalur transportasi air, lokasi berdagang dan berusaha, kegiatan budidaya ikan air tawar, dan menjadi lokasi tempat tinggal/menetap. Tempat tinggal yang dibuat masyarat disebut dengan lanting atau rumah terapung. Jumlah lanting atau rumah terapung di lingkungan Sungai Kahayan \pm 342 buah. Seluruh kegiatan rumah tangga dilakukan di atas lanting. Mulai dari memasak, mencuci, makan, minum, dan kakus. Kegiatan tersebut berpotensi mencemari lingkungan air Sungai Kahayan karena akan menghasilkan bahan sisa berupa sampah dan limbah yang langsung dibuang ke badan air Sungai Kahayan. Sampah dan limbah yang dihasilkan merupakan masalah besar bagi lingkungan karena akan menyebabkan perubahan fisika, kimia maupun biologi dari air Sungai Kahayan. Untuk itu diperlukan peran pemerintah dalam mengatasi permasalahan tersebut, agar lingkungan Sungai Kahayan dapat terjaga kelestariannya.
\end{abstract}

Kata kunci : Lanting, Pencemaran, Lingkungan, Sungai Kahayan

\section{PENDAHULUAN}

Air merupakan salah satu materi abiotik yang sangat melimpah jumlahnya. Air merupakan bahan pelarut yang di butuhkan oleh semua makhluk hidup dalam kehidupannya. Permasalahan mengenai air terus meningkat seiring dengan laju pertumbuhan penduduk terutama mengenai kualitas air. Kualitas air yang terganggu akan mempengaruhi jumlah air bersih yang diperuntukkan untuk di konsumsi oleh masyarakat. Perlu diketahui bahwa jumlah air yang ada di bumi selalu stabil dari segi kuantitasnya, akan tetapi dari segi kualitas mengalami penurunan. Sehingga kebutuhan akan air bersih sangat rawan untuk dapat terpenuhi, apalagi di musim kemarau. Sumber-sumber air yang ada seperti mata air yang di pegunungan maupun di dalam hutan mengalami pengurangan bahkan hilang, hal ini disebabkan oleh pengrusakan lingkungan seperti deforestasi secara besar besaran. Pengrusakan hutan, yang diubah fungsinya menjadi lahan di setiap tahunnya kurang lebih 2,5 juta hektar. Hutan yang sudah di rusak dijadikan lahan pertanian, peternakan, perkebunan, perumahan, industri, maupun menjadi kantor instansi pemerintah. Perubahan fungsi hutan menjadi lahan akan mempengaruhi sumber air yang diperlukan oleh masyarakat. Sehingga ketika musim penghujan menimbulkan bencana seperti banjir dan tanah longsor, sedangkan pada musim kemarau, pasokan air bersih berkurang. Kondisi lingkungan yang tidak kondusif seperti ini akan menimbulkan permasalahan baru dan akan mengganggu kenyamanan hidup manusia. 
Selain permasalahan kekurangan air bersih, tentu akan merambat ke sektor lain. seperti terganggunya kesehatan. Terganggunya kesehatan akan menyebabkan bertambahnya beban hidup bagi masyarakat luas. Misalnya seperti aktivitas masyarakat yang ada di lingkungan Sungai Kahayan Kota Palangka Raya Kalimantan Tengah. Aktivitas yang dilakukan masyarakat sekitar Sungai Kahayan, terutama yang tinggal di atas Lanting (Rumah Terapung) diantaranya seperti memasak menggunakan air sungai, mandi, mencuci, minum menggunakan air sungai, dan segala aktivitas kehidupan. Kegiatan yang dilakukan masyarakat tersebut tentu akan meningkatkan permasalahan lingkungan di Sungai Kahayan seperti pencemaran. UU No.32 Tahun 2009 tentang Perlindungan dan Pengelolaan Lingkungan Hidup menyatakan bahwa pencemaran lingkungan hidup adalah masuk atau dimasukkannya makhluk hidup, zat, energi, dan/atau komponen lain ke dalam lingkungan hidup oleh kegiatan manusia sehingga melampaui baku mutu lingkungan hidup yang telah ditetapkan.

Kondisi dan permasalahan yang ada tentu akan menimbulkan dampak lingkungan hidup seperti di lingkungan Sungai Kahayan. Dampak lingkungan hidup merupakan pengaruh perubahan pada lingkungan hidup yang diakibatkan oleh suatu usaha dan/atau kegiatan. Berdasarkan kondisi lingkungan Sungai Kahayan maka penelitian ini berjudul "Pengaruh aktivitas masyarakat yang tinggal di lanting (rumah terapung) terhadap pencemaran lingkungan Sungai Kahayan Kota Palangka Raya Kalimantan Tengah."

\section{METODE PENELITIAN \\ Metode Penelitian}

Penelitian dilakukan di lingkungan Sungai Kahayan Pada Tanggal 16-17 Bulan September 2016. Lokasi penelitian di lingkungan Sungai Kahayan.

\section{Alat Penelitian}

Alat yang digunakan untuk memperoleh data dalam penelitian yaitu seperti Kamera, Recorder, Perahu Kecil.

\section{Jenis Penelitian}

Penelitian ini berdasarkan atas tingkatannya termasuk penelitian deskriptif. Penelitian deskriptif bertujuan untuk menggambarkan lebih teliti ciri-ciri sesuatu seperti gambaran tentang gejala/suatu masyarakat tertentu, menentukan frekuensi terjadinya sesuatu, dan prosedur penelitian harus mengikuti ketentuan-ketentuan yang baku. Penelitian deskriptif bias harus diperkecil dan tingkat keyakinan harus maksimal.

\section{Teknik Pengumpulan Data}

Teknik pengumpulan data yang digunakan adalah teknik observasi jenis nonpartisipan dan interview jenis free talk. Teknik penelitian secara observasi jenis nonpartisipan yaitu peneliti berada di luar masyarakat yang diamati dan tidak ikut dalam kegiatan-kegiatan masyarakat yang dilakukan. Dengan demikian peneliti akan lebih leluasa mengamati tingkah laku yang terjadi, seperti tingkah laku masyarakatyang tinggal di lingkungan Sungai Kahayan yang berpotensi menimbulkan pencemaran.

Penunjang teknik pengambilan data yang dilakukan peneliti selain menggunakan teknik observasi nonpartisipan yaitu teknik Interview jenis free talk. Teknik pengambilan data dengan teknik interview free talk yaitu peneliti bertindak sebagai pengumpul, penilai fakta dan partisipan. Dalam hal ini peranan pendekatan pribadi sangat menentukan. 
Kerangka penelitian yang dilakukan sebagai berikut.

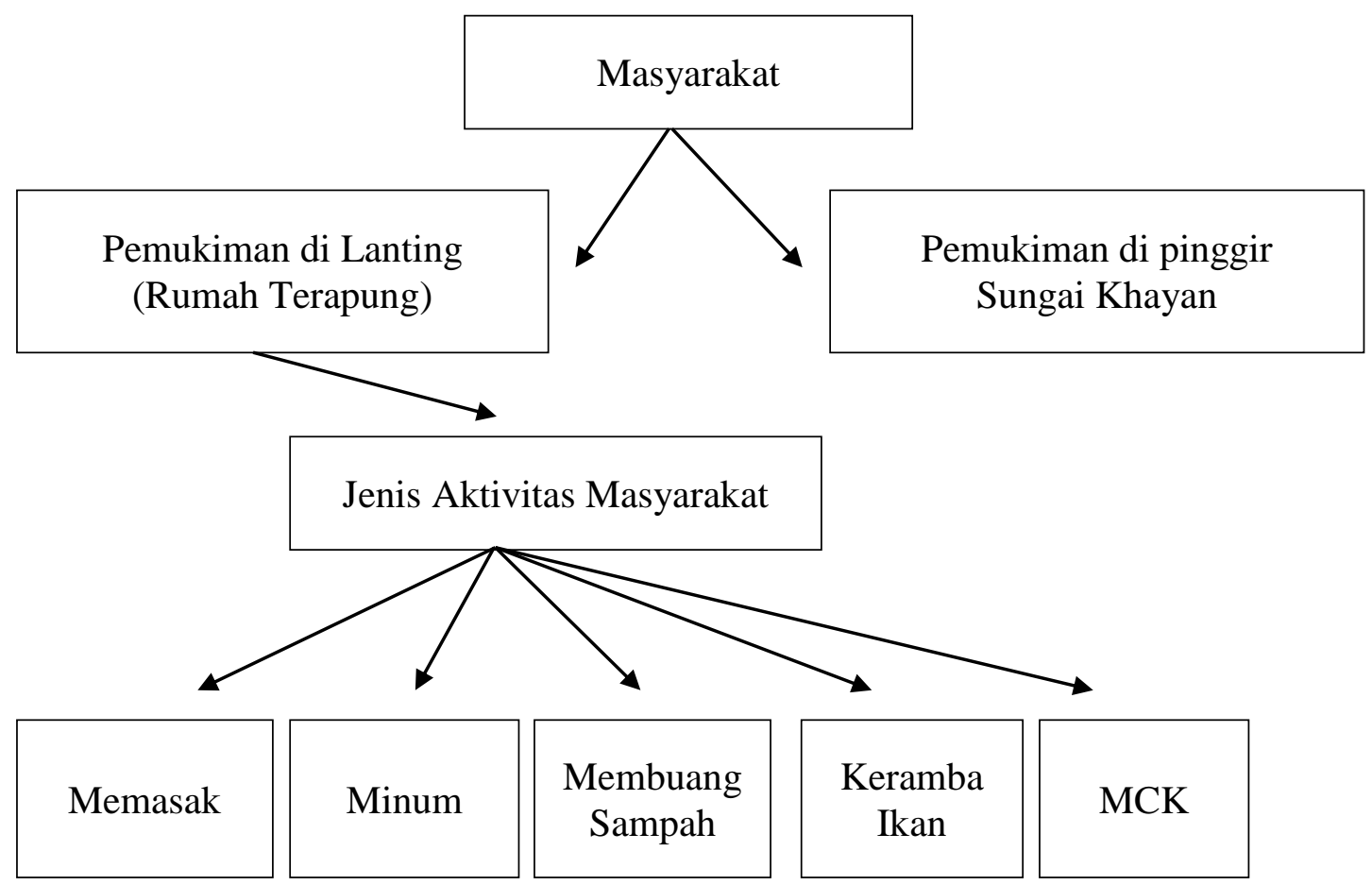

Gambar 1. Kerangka penelitian

\section{HASIL DAN PEMBAHASAN}

Penelitian yang dilakukan di lingkungan Sungai Kahayan mengenai Pengaruh aktivitas masyarakat yang tinggal di lanting (rumah terapung) terhadap pencemaran lingkungan Sungai Kahayan Kota Palangka Raya Kalimantan Tengah. Data rumah terapung (lanting) yang diperoleh sebanyak 342 buah lanting. Lokasi pengamatan di lingkungan Sungai Kahayan daerah Pahandut Seberang.

Kegiatan kehidupan sehari-hari dilaksanakan di atas lanting (rumah apung) seperti memasak, mencuci, minum, makan, mandi, dan membuang sampah. Perhatikan Tabel berikut.

Tabel 1. Jenis Kegiatan di atas lanting (rumah terapung)

\begin{tabular}{clc}
\hline No & \multicolumn{1}{c}{ Jenis Kegiatan } & $\begin{array}{c}\text { Pelaksanaan di atas } \\
\text { lanting (rumah terapung) }\end{array}$ \\
\hline 1 & Memasak & $\sqrt{ }$ \\
2 & Mencuci & $\sqrt{ }$ \\
3 & Makan & $\sqrt{ }$ \\
4 & Minum & $\sqrt{ }$ \\
5 & Mandi & $\sqrt{ }$ \\
6 & Membuang Sampah & $\sqrt{ }$ \\
Keterangan : & \\
$\sqrt{=}$ ya & \\
$-=$ tidak &
\end{tabular}

Aktivitas kehidupan manusia dalam memenuhi kebutuhan hidup menyebabkan timbulnya permasalahan bagi lingkungan, baik lingkungan darat maupun lingkungan perairan seperti sungai. Permasalahan lingkungan tersebut dapat menyebabkan menurunnya kualitas air, tanah, dan udara. Peningkatan kualitas sumberdaya manusia disertai penyediaan sarana dan prasarana menjadi langkah yang paling tepat untuk menurunkan tingkat pencemaran lingkungan.

Kegiatan yang dilakukan manusia akan menghasilkan suatu permasalahan dan perlu mendapatkan perhatian. Permasalahanpermasalahan tersebut jika tidak di atasi dengan baik akan membutuhkan tenaga, waktu, dan biaya yang besar untuk menyelesaikannya. Misalnya permasalahan akan sampah, limbah, dan sisa kegiatan dapur, serta kegiatan penunjang kehidupan lainnya.

Permasalahan lingkungan sungai seperti Sungai Kahayan yang ada di wilayah Kota Palangka Raya Kalimantan Tengah perlu untuk diperhatikan. Karena sebagian besar kegiatan masyarakat dilaksanakan di lingkungan Sungai Kahayan seperti tempat tinggal (lanting), sarana transportasi, dan budidaya ikan air tawar (keramba). Berdasarkan informasi yang diperoleh dari 
warga sekitar Sungai Kahayan, bahwa banyak ikan air tawar Sungai Kahayan yang punah dan semakin sulit untuk ditemukan.

Permasalahan yang terjadi di lingkungan Sungai Kahayan yang disebabkan oleh aktivitas masyarakat misalnya masyarakat yang tinggal di atas rumah terapung atau lanting harus segera dicarikan solusi agar pencemaran lingkungan yang terjadi di lingkungan Sungai Kahayan dapat diminimalir dengan baik. Bahan pencemar yang memasuki perairan Sungai Kahayan baik dari sisa makanan, minuman, sampah, kakus, sabun detergent dapat menyebabkan penurunan kadar oksigen di dalam air Sungai Kahayan.

Bahan pencemar yang berasal dari limbah domestik atau rumah tangga akan teroksidasi di Sungai Kahayan. Kadar oksigen terlarut di perairan Sungai Kahayan apabila mencapai saturasi (tingkat jenuh) dan berada dalam kesetimbangan dengan kadar oksigen di atmosfer maka proses aerasi tidak akan berlangsung. Aerasi adalah proses transfer oksigen dari atmosfir ke perairan melalui proses difusi (Effendi, 2003).

Tabel 2. Koefisien Transfer Oksigen di Air

\begin{tabular}{llc}
\hline \multicolumn{1}{c}{ Tipe Perairan } & $\mathrm{K}_{\mathrm{l}}(\mathrm{m} / \mathrm{hari})$ \\
\hline 1. & Air tergenang & $0,1-0,15$ \\
2. & Air tercemar berwarna & 0,5 \\
& kehitaman & 3,0 \\
3. & Air laut & \\
4. & Air mengalir & 2,0 \\
& a. Kecepatan $10 \mathrm{~m} /$ menit & 7,0 \\
b. Kecepatan $15 \mathrm{~m} /$ detik & \\
\hline
\end{tabular}

Sumber : Effendi, 2003

Penurunan kadar oksigen perairan salah satunya disebabkan adanya limbah organik yang membutuhkan oksigen untuk melakukan proses dekomposisi. Oksigen di air relatif rendah sehingga dengan adanya bahan organik yang terus menerus memasuki wilayah air akan menyebabkan perubahan fisik, kimia pada air sungai dan meningkatnya jumlah mikroorganisme seperti air di Sungai Kahayan. Perubahan fisik air diantaranya seperti kekeruhan, kekentalan, warna, bau, dan suhu air sungai. Perubahan kimia pada air Sungai Kahayan seperti meningkatnya tingkat keasaman air. Peningkatan jumlah mikroorganisme di perairan Sungai Kahayan akan mengganggu keseimbangan ekosistem yang ada si Sungai
Kahayan. Hal ini akan berpengaruh terhadap kelestarian lingkungan Sungai Kahayan. Terlebih lagi air Sungai Kahayan dijadikan sebagai bahan baku air bersih PDAM Kota Palangka Raya.

Selain penurunan kadar oksigen di air Sungai Kahayan yang disebabkan oleh pembuangan sampah dan limbah rumah tangga seperti sisa makanan secara sembarangan akan menyebabkan penurunan kualitas air seperti Air Sungai Kahayan. Sisa bahan makanan biasanya masih mengandung senyawa atau bahan-bahan organik seperti karbohidrat, protein, lemak, dan asam nukleat.

Tabel 3. Komposisi Limbah Organik

\begin{tabular}{clc}
\hline & Jenis Bahan Organik & Persentase $(\%)$ \\
\hline 1. & Lemak & 30 \\
2. & Protein & 25 \\
3. & Abu & 21 \\
4. & Asam amino, kanji & 8 \\
5. & Lignin & 6 \\
6. & Selulosa & 4 \\
7. & Hemiselulosa & 3 \\
8. & Alkohol & 3 \\
\hline Sumber $:$ Effendi,2003
\end{tabular}

Tabel 4. Parameter dan Tingkat Pencemaran Air

\begin{tabular}{clccc}
\hline \multirow{2}{*}{ Parameter } & \multicolumn{3}{c}{ Tingkat Pencemaran } \\
\cline { 2 - 4 } & Berat & Sedang & Ringan \\
\hline 1. & Padatan Total & 1000 & 500 & 200 \\
(mg/liter) & & & \\
2. & Bahan padatan & 12 & 8 & 4 \\
& terendapkan (ml/liter) & & & \\
3. & BOD (mg/liter) & 300 & 200 & 100 \\
4. COD (mg/liter) & 800 & 600 & 400 \\
5. N total (mg/liter) & 85 & 50 & 25 \\
6. Amonia-N (mg/liter) & 30 & 30 & 15 \\
7. & Klorida (mg/liter) & 175 & 100 & 15 \\
8. Alkalinitas (mg/liter & 200 & 100 & 50 \\
& CaCO $)$ & & & \\
9. & Minyak dan lemak & 40 & 20 & 0 \\
\hline Sumber : Effendi, 2003 & & &
\end{tabular}

Sumber : Effendi, 2003

Lanting atau rumah terapung yang ada di Sungai Kahayan berpotensi mencemari lingkungan Sungai Kahayan jika tidak dikelola dengan baik. Sehingga Pemerintah sebagai pemangku kebijakan harus dapat memberikan solusi pada permasalahan tersebut seperti melakuka sosialisasi mengenai pentingnya menjaga lingkungan serta meningkatkan kualitas sumberdaya manusia sehingga permasalahan tersebut dapat diminimalisir. 


\section{KESIMPULAN}

Masyarakat yang tinggal di lanting atau rumah terapung lingkungan Sungai Kahayan dengan jumlah \pm 342 buah berpotensi mencemari lingkungan air Sungai Kahayan. Aktivitas yang dilakukan masyarakat lebih dominan ada di lanting atau rumah terapung. Kegiatan tersebut seperti memasak, mandi, makan, minum, mandi, kakus, dan mencuci. Kegiatan-kegiatan tersebut merupakan kegiatan yang dapat memberikan dampak terhadap penurunan kualitas lingkungan Sungai Kahayan.

\section{DAFTAR PUSTAKA}

Agus, M., 2007, Restorasi Sungai, Gadjah Mada University Press, Yogyakarta.
Arif, Z., 2014, Dasar-dasar Ilmu Lingkungan, Salemba Teknika, Jakarta Selatan.

Chafid, F., 2007, Analisis Mengenai Dampak Lingkungan Prinsip Dasar dalam Pembangunan, Liberty, Yogyakarta.

Daryanto, dkk., 2013, Pengantar Pendidikan Lingkungan Hidup, Gava Media, Yogyakarta.

Efendi, H., 2003, Telaah Kualitas Air, Kanisius, Yogyakarta.

Sukandarrumidi, 2006, Metodelogi Penelitian, Gadjah Mada University Press, Yogyakarta.

UU. No. 32 Tahun 2009 Tentang Perlindungan dan Pengelolaan Hidup. Kementrian Lingkungan Hidup 